Acta Univ. Sapientiae, Alimentaria, 12 (2019) 70-79

DOI: 10.2478/ausal-2019-0005

\title{
Determination of drying parameters of carrot pomace
}

\author{
É. Molnos \\ e-mail: molnoseva@uni.sapientia.ro \\ Z. Vajda \\ e-mail: vajdazita96@gmail.com \\ Sapientia Hungarian University of Transylvania (Cluj-Napoca, Romania), \\ Faculty of Economics, Socio-Human Sciences and Engineering, \\ Department of Food Science, RO-530104 Miercurea Ciuc, 1 Libertăţii Sq.
}

\begin{abstract}
Carrot is one of the most important root vegetables rich in bioactive compounds such as carotenoids and dietary fibres, with appreciable levels of several other functional components and having significant health-promoting properties. Therefore, it is cultivated on a large scale throughout the world. The by-product (pomace) resulted during carrot juice production is used mainly as animal feed although it contains many valuable components and could therefore be used profitably in the food industry, too. Carrot pomace needs to be preserved by drying as otherwise it deteriorates rapidly. In our research, we studied the infrared drying kinetics of carrot pomace at various temperatures, the obtained data being very important in the drying practice.
\end{abstract}

\section{Introduction}

Carrots (Daucus carota L.) are grown and consumed in large quantities worldwide, this being also the case of our region as it is the second most consumed vegetable after potato (Bogdan, 2017). Carrot roots are traditionally used in salads and soups and could be commercially converted into nutritionally rich

Keywords and phrases: integrated processing of carrots, convective drying, infrared drying, rate constant, dietary fiber, carotenoids 
processed products such as juice, concentrate, dried powder, canned products, etc. (Sharma et al., 2012; Barzee et al., 2019). Carrot juice and its blends are the most popular non-alcoholic beverages, and a steady increase in carrot juice consumption has been reported from various countries (Sharma et al., 2012).

Unfortunately, the yield associated with carrot juice production is quite low, wherefore up to $50 \%$ of the raw material remains as pomace, which is generally disposed of as feed or manure (Surbhi et al., 2018).

Carrot has high levels of $\alpha$ - and $\beta$-carotene (Kumar et al., 2012), which are precursors of vitamin A for the human organism, the latter being essential for vision. Carrot is also rich in fibres, having many beneficial effects on children's and adults' health (Alam et al., 2013; Surbhi et al., 2018). The benefits of carrots cannot be overestimated, especially when it comes to food and baby food.

Carrot pomace containing high amount of $\beta$-carotene could be profitably used for the supplementation of products such as cake, bread, biscuits, and extruded products and the preparation of several types of functional products (Kumar et al., 2010; Gayas et al., 2012; Sharma et al., 2012; Ahmad et al., 2016).

In Romania, the area cultivated with carrot is over 8,000 ha (according to Eurostat) with an average of 198,939 tons of carrot being grown between 2014 and 2016 (MADR, 2017). In recent years, consumers' demand for natural fruit and vegetable juices has increased, and as a result more and more businesses have started to process fruit and vegetable juices. At the same time, carrot residue is being produced in increasing quantities, and the further processing of this may bring economic benefits.

Since carrot pomace is perishable as it contains about $85 \%$ (wet basis) moisture (Upadhyay et al., 2008; Kumar et al., 2012), its shelf life could be increased by drying or dehydration for further use (Alam et al., 2013) - for example, to make extrudate, flavoured breads or cakes. Fresh carrot pomace - when properly dried, packed, and stored - stays available for later use in fibre-rich products (Alam et al., 2013; Sahni \& Shere, 2018).

Drying of materials having high moisture content is a complicated process, involving simultaneous heat and mass transfer (Kumar et al., 2012; Ahmed, 2018).

The most conventional dying method is the convective hot air drying (Sarkar \& Sharma, 2011). Upadhyay et al. (2008) already reported results referring to the hot air oven drying of carrot pomace, the moisture content, ascorbic acid, $\beta$-carotene, crude fibre and ash content of the analysed samples (Upadhyay et al., 2008). 
In order to improve the drying efficiency and product quality, some other techniques, such as microwave, infrared, etc., have been combined with the hot air drying of vegetables ( Ly \& Zhang, 2017). The infrared (IR) radiation heating technology is a new environment-friendly heating technology with its intrinsic advantages such as high heat transfer and drying rate, uniform temperature distribution, nutrient loss reduction, and significant energy saving (Krishnamurthy et al., 2008; Riadh et al., 2015). Further development and application of IR-related processing technology and equipment will contribute to achieving sustainable agricultural and food processing and obtaining highquality, high-value, and healthy vegetable food products ( Wu et al., 2017; Ly \& Zhang, 2017).

In general, the moisture content of the materials does not refer only to water, but it includes all substances (i.e. fats, oils, alcohol, solvents, etc.) that evaporate when the sample is heated. In carrot pomace used for the experiments, moisture content could be assumed as being mainly water since carrot contains a minimal amount of fats (0.2-0.3 g/100 g) (Chen \& Mujumdar, 2008; Butt \& Sultan, 2011; Surbhi et al., 2018), and samples have undergone only physical operations. The conventional drying chamber method for moisture content analysis (Molnár, 2015) requires a longer measuring period, while the sample is heated from the outside to the inside by a hot air current so as to remove the moisture convectively. In contrast, the moisture content determination by thermogravimetric method (as used by the Kern moisture meter) is associated with sample warming from the inside to the outside since the radiation applied penetrates mainly the sample in order to be transformed inside of it into heat energy (Anonymus, 2010). The thermogravimetric method follows the same principle as a conventional method, i.e. measuring the weight of the sample before and after heating and determining the moisture content from the weight difference. Due to the automatic operation, without manipulation and cooling of the probes, this method requires a shorter measuring time.

The purpose of this study is to characterize the infrared drying of carrot pomace at different temperatures and to compare drying kinetics for future practical use. Temperature values have been selected taking into account the recommendations of several studies (Sharma et al., 2012; Alam et al., 2013) to preserve the quality of all valuable components of carrot pomace. 


\section{Materials and methods}

For the research, industrial carrot juice production by-product (carrot pomace) was used. After harvesting, the carrot was transported to the company's warehouse. After being washed with tap water, it was grinded (approximately 3-5 $\mathrm{mm}$ in size, pieces of different shapes) and pressed by a belt filter press (Voran EBP650). The resulting carrot pomace was frozen until the laboratory experiments were performed.

For laboratory drying measurements, a KERN MLB MB 10 moisture balance with $400 \mathrm{~W}$ mercury vapour lamp and digital scale with three decimal places was used. Pomace drying was studied at five different temperatures, i.e. $50,55,60,65$, and $70^{\circ} \mathrm{C}$. For each measurement, $5 \mathrm{~g}$ of carrot pomace was used (more precisely, between 5.004 and $5.012 \mathrm{~g}$ ) and spread evenly on the $70.85 \mathrm{~cm}^{2}$ surface sample plate $\left(d_{\text {plate }}=95 \mathrm{~mm}\right)$. Weight data was recorded every 2 minutes until a constant weight was reached. The collected data was processed with Microsoft Excel and Statistica 8.0 (StatSoft, Inc.) programs.

\section{Mathematical modelling}

The following mathematical models were used to characterize the drying rate and to calculate the drying constants (Barbosa-Cánovas \& Vega-Mercado, 1996; Szép et al., 2017):

- the moisture content (wet basis) of carrot pomace at time $\tau$ :

$$
w_{i}=\frac{m_{i}-m_{e d p}}{m_{i}}, \frac{k g \text { moisture }}{k g \text { wet basis }},
$$

where: $m_{i}$ - the sample weight at time $\tau, \mathrm{g} ; m_{e d p}$ - the final weight of the sample (when no further moisture removal was recorded at a particular drying temperature), g;

- the moisture content (dry basis) of carrot pomace at time $\tau$ :

$$
W_{i}=\frac{m_{i}-m_{e d p}}{m_{i}}, \frac{k g \text { moisture }}{k g d r y \text { basis }},
$$

- drying rate:

$$
r_{\text {drying }}=-\frac{\Delta w}{\Delta \tau}=\frac{w_{i+1}-w_{i}}{\tau_{i+1}-\tau_{i}} \min ^{-1} \text { or } \mathrm{s}^{-1}
$$

- drying time:

$$
\tau=\frac{m}{S \cdot k}\left(\frac{w_{1}-w_{c r}}{w_{c r}-w_{e q}}+\ln \frac{w_{c r}-w_{e q}}{w_{f}-w_{e q}}\right), s,
$$


where: $m$ - the mass of the wet material subjected to drying, g; $S$ - transfer surface, $\mathrm{m}^{2} ; w_{1}, w_{f}, w_{c r}, w_{e q}$ - the initial, final, critical, and equilibrium (corresponding to ambient conditions) moisture content, $\mathrm{kg}$ moisture/ $\mathrm{kg}$ wet basis; $k$ - rate constant, $\mathrm{kg} /\left(\mathrm{m}^{2} \cdot \mathrm{s}\right)$.

\section{Results and discussions}

Infrared drying of the carrot pomace was carried out at five different temperatures (i.e. $50-70{ }^{\circ} \mathrm{C}$ with $5^{\circ} \mathrm{C}$ steps) in three successive runs. The data collected for each series is shown in Fig. 1a. There was no significant difference in the data values, so the standard deviation is not plotted.

(a)

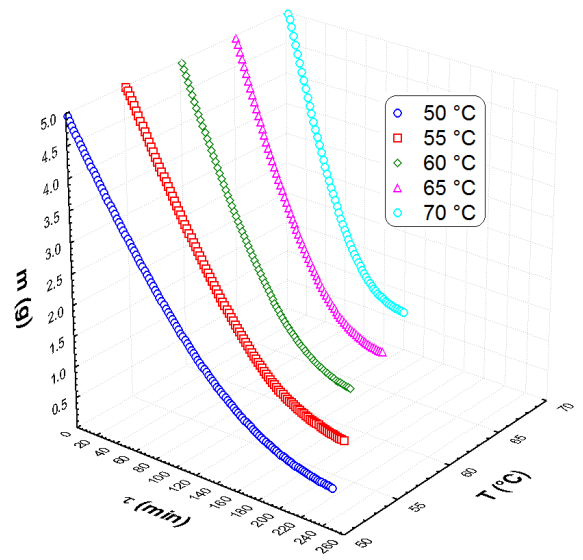

(b)

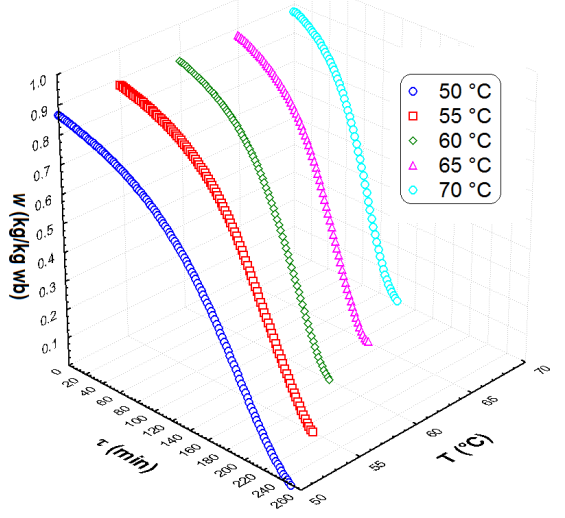

Figure 1: Measured weights (a) and drying curves (b) as functions of drying time and temperature 
Drying time decreased from $250 \mathrm{~min}$ to $120 \mathrm{~min}$ as temperature rose; the higher temperature favoured the faster removal of moisture. The same observation was made by Upadhyay et al. (2008), but drying time was much longer (decreased from 7.5 to 5 hours) due to the different drying method used (Upadhyay et al., 2008). As for the initial moisture content of the carrot pomace samples (calculated with equation (1)), there is no such difference between the two experiments. In our case, the average initial moisture content of the samples was $87.25 \pm 0.37 \%$ (wet basis), while before the hot air convective drying it was $85.62 \%$ (wet basis) (Upadhyay et al., 2008).

Drying curves (moisture content versus time) recorded at different temperatures are shown in Fig. 1b. The trend of the drying curves is typical for vegetables and is similar to other agricultural products reported as the moisture ratio decreased exponentially (Ahmed, 2018).

The drying curves are useful to plot the change in drying rate (eq. (3)) as function of moisture content, too (Fig. 2).

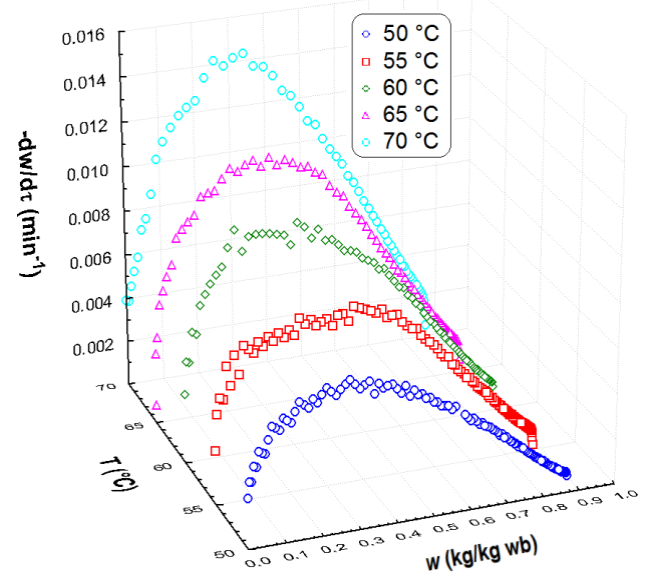

Figure 2: Drying rate changes as function of moisture content at different temperatures

As we can see from the curves, there are two different drying periods: the first, the so-called constant drying rate period, and the descending rate drying period. The value of moisture corresponding to the point of inflection is described in the literature as critical moisture content $\left(w_{c r}\right)$. By the end of the second period, the moisture in the sample will run out, i.e. it will reach the equilibrium moisture $\left(w_{e q}\right)$ level. In order to express the value of the dry- 
ing rate constant $(k)$ from the drying time equation (eq. (4)), these values must first be determined using the drying curves (Fig. 2). These values are summarized in Table 1. It has to be noted that during the experiments, the carrot pomace was carefully distributed evenly over the sample plate of the balance; therefore, the value of the drying surface was initially equal with the plate surface, numerically: $S=0.00708 \mathrm{~m}^{2}$. Despite the varying shrinkage of the carrot pomace during the measurements, it was not taken into account in our calculations. The calculated rate constant values from equation (4) are listed in Table 1.

Table 1: Calculated parameters of infrared drying at various temperatures

\begin{tabular}{|c|c|c|c|c|c|c|c|}
\hline \multirow{2}{*}{$\begin{array}{c}\text { Drying } \\
\text { temperature, } \\
{ }^{\circ} \mathrm{C}\end{array}$} & \multicolumn{2}{|c|}{$\underset{\tau}{\text { Drying time, }}$} & \multicolumn{4}{|c|}{ Moisture content, $\mathrm{kg} / \mathrm{kg}$ wb } & \multirow{2}{*}{$\begin{array}{l}\text { Rate constant, } \\
\mathrm{k}, \\
10^{-3} \mathrm{~kg} /\left(\mathrm{m}^{2} \cdot \mathrm{s}\right)\end{array}$} \\
\hline & $\min$ & $\mathbf{s}$ & $\mathrm{w}_{1}$ & $\mathrm{w}_{\mathrm{cr}}$ & $\mathrm{w}_{\mathrm{eq}}$ & $w_{f}$ & \\
\hline 50 & 250 & 15,000 & 0.8663 & 0.185 & 0.02 & 0.004 & 0.306 \\
\hline 55 & 210 & 12,600 & 0.8775 & 0.186 & 0.02 & 0.005 & 0.368 \\
\hline 60 & 166 & 9,960 & 0.8709 & 0.181 & 0.02 & 0.006 & 0.478 \\
\hline 65 & 148 & 8,880 & 0.8749 & 0.195 & 0.02 & 0.002 & 0.489 \\
\hline 70 & 120 & 7,200 & 0.8730 & 0.231 & 0.02 & 0.008 & 0.579 \\
\hline
\end{tabular}

In the studied drying temperature interval, the rate constant variation is linear in function of temperature. As the value of coefficient of determination is close to $1\left(R^{2}=0.9627\right)$, this suggests that the equation (5) is appropriate for drying rate constant estimation at various drying temperatures:

$$
k=1.33 \cdot 10^{-5} \cdot T-0,0004
$$

\section{Conclusions}

Based on the study, we concluded that the carrot pomace drying with infrared radiation method would be a better choice compared to hot air convective drying due to significantly shorter drying time. The calculated rate constants of infrared drying at various temperatures could serve as a good starting point for industrial research and developments that need to be carried out to scale up this drying method. Dried carrot pomace can be easily grinded to powder and can be incorporated in bakery products as a cheap source of dietary fibres. Furthermore, this processing alternative represents a good opportunity for the vegetable juice manufacturing industry for efficient waste management and additional profit. 


\section{References}

[1] M. Ahmad, T. A. Wani, S. M. Wani, F. A. Masoodi, A. Gani, Incorporation of carrot pomace powder in wheat flour: Effect on flour, dough and cookie characteristics. Journal of Food Science and Technology, 53. 10. (2016) 3715-3724.

[2] J. Ahmed, Drying of vegetables: Principles and dryer design (Chapter 16). In: M. Siddiq, M. A. Uebersax (eds.), Handbook of vegetables and vegetable processing, vol. 1, $2^{\text {nd }}$ edition. John Wiley \& Sons Ltd. (2018) 381-405.

[3] M. S. Alam, K. Gupta, H. Khaira, M. Javed, Quality of dried carrot pomace powder as affected by pretreatments and methods of drying. Agricultural Engineering International: The CIGR e-journal, 15. 4. (2013) 236-243.

[4] XXXX, Electronic moisture meter - Operating Manual, 16. General information concerning moisture analysis. (2010).

URL: http://www. kern-sohn.com/manuals/files/English/MLB_N-BAe-1021.pdf (accessed: 22.07.2019).

[5] G. V. Barbosa-Cánovas, H. Vega-Mercado, Dehydration mechanisms (Chapter 4). In: Dehydration of Foods. Springer, Dortrecht (1996) 101156.

[6] T. J. Barzee, H. M. El-Mashad, R. Zhang, Z. Pan, Carrots (Chapter 12). In: Z. Pan, R. Zhang, S. Zicari (eds.), Integrated processing technologies for food and agricultural by-products. Elsevier Academic Press. (2019) 297-330.

[7] M. Bogdan, Cultura morcovului [Carrot culture]. Lumea Satului, 1. (2017) 16-17.

[8] M. S. Butt, M. T. Sultan, Nutritional profile of vegetables and its significance to human health (Chapter 5). In: N. K. Sinha (ed.), Handbook of vegetables and vegetable processing. Blackwell Publishing Ltd. (2011) 107-123.

[9] X. D. Chen, A. S. Mujumdar, Drying technologies in food processing. Blackwell Publishing Ltd., Oxford, (2008). 
[10] B. Gayas, R. N. Shukla, B. M. Khan, Physico-chemical and sensory characteristics of carrot pomace powder enriched defatted soyflour fortified biscuits. International Journal of Scientific and Research Publications, 2. 8. (2012) 1-5.

[11] K. Krishnamurthy, H. K. Khurana, S. Jun, J. Irudayaraj, A. Demirici, Infrared heating in food processing: An overview. Comprehensive Reviews in Food Science and Food Safety, 7. (2008) 1-13.

[12] N. Kumar, B. C. Sarkar, H. K. Sharma, Development and characterization of extruded product of carrot pomace, rice flour and pulse powder. African Journal of Food Science, 4. 11. (2010) 703-717.

[13] N. Kumar, B. C. Sarkar, H. K. Sharma, Mathematical modelling of thin layer hot air drying of carrot pomace. Journal of Food Science and Technology, 49. 1. (2012) 33-41.

[14] W. Ly, M. Zhang, Main current vegetable drying technology I. Hot airflow drying and related combination drying (Chapter 1). In: M. Zhang, B. Bhandari, Z. Fang (eds.), Handbook of drying of vegetables and vegetable products. CRC Press, Boca Raton, (2017) 3-21.

[15] Ministerul Agriculturii şi Dezvoltării Regionale (MADR), Strategia naţională pentru programele operaţionale în sectorul de fructe şi legume 2018-2020 [National strategy for operational programmes in the fruit and vegetable industry 2018-2020]. MADR, Direcţia Generală Politici Agricole şi Strategii, Bucharest (2017).

[16] K. Molnár, Experimental techniques in drying (Chapter 2). In: A. S. Mujumdar (ed.), Handbook of industrial drying, $4^{\text {th }}$ edition. CRC Press, Boca Raton (2015).

[17] M. H. Riadh, S. A. B. Ahmad, M. H. Marhaban, A. C. Soh, Infrared heating in food drying: An overview. Drying Technology, 33. (2015) $322-335$.

[18] P. Sahni, D. M. Shere, Utilization of fruit and vegetable pomace as functional ingredient in bakery products: A review. Asian Journal of Dairy and Food Research. (2018) 1-10.

[19] B. C. Sarkar, H. K. Sharma, Carrots (Chapter 28). In: N. K. Sinha (ed.), Handbook of vegetables and vegetable processing. Blackwell Publishing Ltd. (2011) 565-580. 
[20] K. D. Sharma, S. Karki, N. S. Thakur, S. Attri, Chemical composition, functional properties and processing of carrot - A review. Journal of Food Science and Technology, 49. 1. (2012) 22-32.

[21] S. Surbhi, R. C. Verma, R. Deepak, H. K. Jain, K. K. Yadav, A review: Food, chemical composition and utilization of carrot (Daucus carota L.) pomace. International Journal of Chemical Studies, 6. 3. (2018) 29212926.

[22] A. Szép, É. Molnos, C. D. András, Transzport folyamatok és müvelettan II. Müvelettan [Transport phenomena and unit operations II. Unit operations]. Cermi, Iaşi, (2017) 315-352.

[23] A. Upadhyay, H. K. Sharma, B. C. Sarkar, Characterization of dehydration kinetics of carrot pomace. Agricultural Engineering International: The CIGR e-journal, X. (2008).

[24] B. Wu, B. Wang, H. Ma, B. Xu, Z. Pan, Highly efficient vegetable drying technology II: Infrared radiation drying and related combination drying (Chapter 4). In: M. Zhang, B. Bhandari, Z. Fang (eds.), Handbook of drying of vegetables and vegetable products. CRC Press. (2017) $66-80$. 